\title{
DAS CONSEQUÊNCIAS SUCESSÓRIAS DA CONCEPÇÃO POST MORTEM: O DIREITO FUNDAMENTAL À HERANÇA E O PRINĆ́PIO DA SEGURANÇA JURÍDICA
}

\author{
DE LAS CONSECUENCIAS SUCESORIAS DE LA CONCEPCIÓN POST \\ MORTEM: EL DERECHO FUNDAMENTAL A LA HERENCIA Y EL PRINCIPIO \\ DE SEGURIDAD JURÍDICA
}

\author{
${ }^{1}$ Caroline Schneider \\ ${ }^{2}$ Ellen Carina Mattias Sartori
}

\section{RESUMO}

O presente artigo aborda a questão da reprodução humana assistida homóloga post mortem e seus reflexos no direito sucessório. O estudo justifica-se diante dos constantes avanços tecnológicos no campo da ciência médica reprodutiva. A evolução da ciência acarreta várias nuances ao ordenamento jurídico e, ainda que lenta, é mais rápida que o trabalho legislativo. $\mathrm{Na}$ cultura jurídica brasileira, não se tem o costume da tratar da morte. A confecção de testamento fica a margem, sendo comumente utilizada apenas em caso de grandes somas de bens patrimoniais. Porém, principalmente diante do avanço da ciência reprodutiva, dispor sobre filiação, seja a nascida, seja a eventual, em testamento legalmente confeccionado, diminuiria sobremaneira as disputas sucessórias. Tem-se, portanto, como objetivo geral desse estudo, analisar o fenômeno da reprodução humana assistida post mortem com base na Constituição Federal e no Código Civil Brasileiro. Como objetivo específico, o artigo busca sopesar a sucessão de prole concebida post mortem tanto em relação à sucessão testamentária como em relação à sucessão legítima, baseando as ponderações no princípio da segurança jurídica, que deve nortear o sistema jurídico como um todo. Trata-se de uma pesquisa teórica e bibliográfica, com método de abordagem dedutivo, realizada através da análise da legislação constitucional e infraconstitucional, bem como de obras doutrinárias referentes ao tema.

Palavras-chave: Reprodução humana assistida, Concepção post mortem, Direito das sucessões, Direito à herança, Princípio da segurança jurídica

\begin{abstract}
El presente artículo aborda lo asunto de la reproducción humana asistida homóloga post mortem y sus reflejos en el derecho de sucesión. El estudio se justifica ante los constantes avances tecnológicos en el campo de la ciencia médica reproductiva. La evolución de la ciencia implica diversos matices a lo ordenamiento jurídico y, aunque es lenta, es más rápida que el trabajo legislativo. En la cultura jurídica brasileña, no se tiene la costumbre de hacer frente a la muerte. La realización de testamento es el margen y sólo se utilizada en caso de grandes cantidades de activos. Sin embargo, principalmente ante el avanzo de la ciencia reproductiva, preocuparse por la membresía, nacidos, ya sea por nacimiento en testamentojurídicamente

\footnotetext{
${ }^{1}$ Mestra em Direito pela Instituição Toledo de Ensino de Bauru - ITE, Bauru, SP (Brasil). Coordenadora do Núcleo ESA da OAB/SP e advogada e Analista do Seguro Social, na Agência da Previdência Social de Ourinhos, São Paulo., SP. (Brasil). E-mail.: krolschneider@hotmail.com

${ }^{2}$ Mestranda em Direito Constitucional pelo Centro de Pós-Graduação da ITE, Bauru - SP; (Brasil). Especialista em Direito Empresarial pela UEL; Advogada.E-mail.: ecsartori@uol.com.br
} 
hecho disminuirá en gran medida las disputas de sucesión. Se tiene, así, como objetivo general del estudio, analizar el fenómeno de la reproducción humana asistida post mortem con base en la Constitución Federal e en lo Código Civil Brasileño. Como objetivo específico, el artículo busca sopesar la sucesión de prole concebida post mortem tanto en relación a la sucesión testamentaria como en relación a la sucesión legítima, con ponderaciones basadas en el principio de seguridad jurídica, que debe guiar el sistema jurídico en su conjunto. Se trata de una pesquisa teórica y bibliográfica, con método de abordaje deductivo, realizada a través de analice de la legislación constitucional e infra constitucional, así como de obras doctrinarias sobre el tema.

Keywords/Palabras-claves/Mots-clés: Reproducción humana asistida, Concepción post mortem, Derecho de sucesiones, Derecho a la herencia, Principio de seguridad jurídica

\section{INTRODUÇÃO}

Embora a morte seja a única certeza que se tem na vida, dessa nos esquivamos de tratar até que a única opção seja encará-la de frente. Seja pela cultura, por medo, ou mesmo por desconhecimento, as consequências, inclusive jurídicas, da morte geralmente ficam ao bel prazer do tempo e das regras impostas pelo ordenamento jurídico, não havendo, muitas vezes, a preocupação com a situação familiar e patrimonial post mortem.

A morte, como fato jurídico stricto sensu, põe termo à pessoa física, gerando efeitos jurídicos a seus sucessores, conforme preceitua os artigos $6^{\circ}$ e 1.784 do Código Civil vigente, porém, nem sempre foi assim.

No início dos tempos, não havia razão de ser do direito sucessório, pois aos pais cabia apenas obrigação de alimentar seus filhos, mas não de fazê-los seus herdeiros. No entanto, após a segunda metade do século XX e a consagração da propriedade privada, tudo muda de figura e o direito sucessório, como corolário no patrimonialismo individual, ganha espaço nos ordenamentos jurídicos.

$\mathrm{Na}$ Idade Média, surge o princípio da saisine (droit de saisine), segundo o qual a consequência patrimonial da morte é a transferência imediata do acervo do falecido a seus herdeiros. Os bens do de cujus em nenhum momento ficam a mercê da sorte, de imediato há a modificação da titularidade, não havendo que se falar em coisa abandonada (res derelicta) ou em coisas de ninguém (res nullius).

A Constituição Federal vigente (BRASIL, 1988) consagra a propriedade privada em seu artigo $5^{\circ}$, inciso XXII, e como consequência protege a herança no mesmo artigo $5^{\circ}$, inciso XXX, baseada no sistema da divisão necessária, no qual se admite a disponibilidade relativa dos bens quando houver herdeiros necessários. No mesmo sentido, estabelece o artigo 1.846 
do Código Civil de 2002 que: "pertence aos herdeiros necessários, de pleno direito, a metade dos bens da herança, constituindo a legítima" (BRASIL, 2002).

Contudo, o estudo da disciplina legal sucessória faz surgir várias indagações frente à modernidade, abrolhando a obrigação de analisar o assunto de forma alinhada como as novas formações familiares e as técnicas de concepção artificial assistida de futuros herdeiros.

Inúmeros avanços nos campos da medicina e da biotecnologia, assim, fizeram surgir a necessidade de se repensar a disciplina jurídica relativa às sucessões. É notável a dificuldade de o Direito legislado acompanhar as constantes mudanças das relações sociais, tornando evidente a necessidade de estudos que se debrucem sobre essas novas questões referentes aos avanços tecnológicos e a legislação civil.

No que tange à sucessão, a questão da reprodução assistida é tema bastante controvertido. As técnicas de reprodução humana assistida, de finalidade indiscutível, viabilizam o propósito de procriação e a efetivação do planejamento familiar, ditame constitucional consagrado no artigo $226, \S 7^{\circ}$, para inúmeros casais que possuem dificuldades de fertilização natural.

Essas modernas técnicas de reprodução humana, como a criopreservação de embriões para concepção futura, possibilitaram a fecundação mesmo após a morte do doador. Desse modo, não há como negar que o avanço da tecnologia relativa à fertilização assistida repercute juridicamente no âmbito do direito de herança, visto que gera um manancial de questionamentos acerca da possibilidade de se atribuir direitos de filiação e sucessórios à prole concebida.

A temática que envolve a reprodução humana assistida merece um longo tratado a respeito, devido justamente a essa série de questões jurídicas, éticas e morais que podem derivar dessas técnicas. Entretanto, esse não é o objetivo do presente estudo. Desse modo, a ênfase que se pretende dar nesse artigo é em relação à reprodução assistida homóloga post mortem e suas consequências, diante da possibilidade desses descendentes concebidos artificialmente terem direito à sucessão de seu pai pré-morto, fazendo-se a ponderação necessária entre o direito fundamental à herança e a segurança jurídica.

Indubitavelmente, a prole concebida post mortem, com amparo na Constituição e no Código Civil, terá direito à filiação, à herança e ao direito de propriedade e, sendo filho, deve ser considerado como herdeiro, tendo direito de saisine.

Quanto à sucessão testamentária, conforme será analisado, a temática não gera tantas dificuldades, principalmente porque no momento de sua abertura os demais herdeiros e 
legatários já tomariam ciência da possibilidade de existência de prole futura. Porém, quanto à sucessão legítima, a afirmação não se mostra tão confortável, sendo evidente que existe um conflito entre princípios constitucionais, direitos fundamentais e direitos sucessórios. Assim, pretende-se sopesar a questão diante da inexistência de autorização testamentária. O problema que se coloca, por conseguinte, é justamente decorrente da insegurança jurídica que tal situação gera aos demais herdeiros.

No aspecto metodológico, será utilizado o método de orientação de conhecimento dedutivo, partindo de várias premissas apresentadas referentes à vocação hereditária e a concepção post mortem, atreladas ao direito de herança e ao princípio da segurança jurídica, chega-se à conclusão do trabalho.

Quanto à natureza e ao objetivo, trata-se de uma pesquisa teórica, exploratória e explicativa, que busca o aprofundamento do conhecimento sobre o tema. Em relação à fonte de dados, pesquisa é bibliográfica, sendo utilizada a documentação indireta, empregando-se a legislação pátria e obras doutrinárias presentes em livros, artigos em periódicos impressos e no meio eletrônico.

\section{A ABERTURA DA SUCESSÃO E SEUS HERDEIROS NECESSÁRIOS}

Com o evento morte está aberta a sucessão hereditária, nos termos do artigo 1.784, do Código Civil, sendo os herdeiros chamados a suceder. Segundo Polleto (2013, p. 103), dáse a "transferência automática dos ativos e passivos que formam a massa entre a pessoa morta e aqueles sobreviventes, qualificados por lei ou mediante ato voluntário, como sucessores e, como tais, aptos a recebê-los", é a concretização do droit de saisine.

Segundo o princípio da saisine, o próprio falecido transmite ao sucessor a propriedade e a posse da herança.

\footnotetext{
Embora não se confundam a morte com a transmissão da herança, sendo aquela pressuposto e causa desta, a lei, por uma ficção, torna-as coincidentes em termos cronológicos, presumindo que o próprio de cujus investiu seus herdeiros no domínio e na posse indireta de seu patrimônio, porque este não pode restar acéfalo.

Para que a transmissão tenha lugar é necessário, porém: a) que o herdeiro exista ao tempo da delação; e b) que a esse tempo não seja incapaz de herdar (GONÇALVES, 2014b, p. 34).
}

A primeira pergunta a ser feita é se o falecido deixou testamento ou se a transmissão seguirá a forma da sucessão legítima, sendo posteriormente convocados os herdeiros.

Havendo testamento, serão convocados os herdeiros necessários, titulares de $50 \%$ da herança, conforme artigo 1.789 do Código Civil, que dispõe que "havendo herdeiros 
necessários, o testador só poderá dispor de metade da herança” (BRASIL, 2002), e os herdeiros contemplados com a disposição de última vontade do falecido.

No caso de não haver testamento, a transmissão dos bens será feita pela forma da sucessão legítima, sendo chamados para suceder apenas os herdeiros necessários, na forma do artigo 1.798 e seguintes do Código Civil. A questão que se pretende analisar nesse artigo se encontra justamente na definição dos herdeiros necessários e na sua consequente possibilidade de sucessão.

De acordo com o artigo 1.845 do Código Civil, "são herdeiros necessários os descendentes, os ascendentes e o cônjuge", e ainda dispõe que "legitimam-se a suceder as pessoas nascidas ou já concebidas no momento da abertura da sucessão". Logo, os descendentes, para herdarem, devem ser nascidos ou nascituros, pela interpretação literal do dispositivo. Quanto ao nascituro, preconiza Veloso (2006, p. 1.494) que:

O conceptus (nascituro) é chamado à sucessão, mas o direito sucessório só estará definido e consolidado se nascer com vida, quando adquire a personalidade civil ou capacidade de direito. O nascituro é ente em formação (spes hominis), um ser que ainda não nasceu. Se o concebido nascer morto, a sucessão é ineficaz.

Logo, os direitos patrimoniais do nascituro são subordinados a condição resolutiva, ou seja, ao nascimento com vida (TARTUCE; SIMÃO, 2013, p. 32). No caso do nascituro, os bens serão confiados a um curador, nos termos do artigo 1.779 do Código Civil, que será normalmente a genitora. Se natimorto, os bens reverterão ao monte mor e serão divididos entre os demais herdeiros necessários. Há que se ponderar que, em nascendo com vida e falecendo instantes depois, irá adquirir os bens e transmiti-los a seus sucessores.

\footnotetext{
Defere-se a sucessão ao nascituro, desde que já concebido no momento da abertura da sucessão (herdeiro póstumo). Posto lhe falte personalidade, é certo que nasciturus pro iam nato habetur quun de eius commodis agitur. Nomeia-se-lhe curador, pois que melius est intacta iura servare quam, vulnerata causa, remedium quaerere. Adquire de imediato a propriedade e a posse da herança, como se já fosse nato desde o momento da abertura da sucessão.

Se, porém nasce morto, deve ser considerado como se nunca tivesse existido. O que morreu, ainda que apenas um instante antes da abertura da sucessão, não é chamado a herdar (PEREIRA, 2001, p. 19).
}

No caso da sucessão do nascituro, concebido em vida, a possibilidade de sucessão se encontra disciplinada no Código Civil, como visto, e não gera grandes controvérsias. Entretanto, muito ainda se discute em relação à concepção post mortem, que será sopesada no presente estudo.

A fecundação ou inseminação artificial post mortem é aquela realizada com embrião ou sêmen conservado por meio de técnicas especiais, após a morte do doador do sêmen. 
Embrião é o ser oriundo da junção de gametas humanos, sendo que há basicamente dois métodos de reprodução artificial: a fertilização in vitro, na qual o óvulo e o espermatozoide são unidos numa proveta, ocorrendo a fecundação fora do corpo da mulher, e a inseminação artificial, consistente na introdução de gameta masculino, por meio artificial, no corpo da mulher, esperando-se que a própria natureza faça a fecundação. O embrião é excedentário quando é fecundado fora do corpo (in vitro) e não é introduzido prontamente na mulher, sendo armazenado por técnicas especiais (SILVA, 2012, p. 1.767-1.768).

Alguns doutrinadores, acertadamente, preconizam que os conceitos de embrião e de nascituro não se confundem (TARTUCE, SIMÃO, 2013, p. 32), isso porque o nascituro já se encontra nidificado no ventre materno. Por outra via, as técnicas de reprodução assistida podem gerar embriões, que, antes da implantação no útero materno, não são considerados nascituros. Entretanto, a questão não é tão simples.

\begin{abstract}
O problema não mais se refere aos nascituros que se encontravam implantados no útero materno, senão aos embriões, congelados em laboratório. Assiste-lhes a condição de nascituros? Ou, ao contrário, são considerados prole eventual, já que não se sabe se serão efetivamente alojados em útero apto a gestá-los? A resposta que se dê gerará diferentes soluções no que toca ao destino da pessoa que morta. Se forem considerados nascituros, terão adquirido a propriedade da quota-parte que lhes toque, o que pode causar inconvenientes gravíssimos se alguns forem embriões congelados. Se, por outro lado, forem considerados prole eventual, afastados da sucessão legítima, poderão restar excluídos da sucessão do pai ou da mãe que não conheceram, mas a quem devem a paternidade biológica (CAHALI; HIRONAKA, 2003, p. 356).
\end{abstract}

Diante dessa situação de dúvida, há quem entenda que o nascituro, e apenas ele, sucede legitimamente e não os embriões:

Considera-se nascituro (“o que está por nascer”) o fruto da concepção (óvulo fertilizado) aninhado no ventre materno. Não basta a concepção externa, obtida em laboratório (fecundação in vitro), mesmo porque passível de conservação por tempo indeterminado (banco de embriões). Exige-se, ao invés, que ocorra a implantação no útero materno (in anima nobile), onde ocorre a nidação, possibilitando seu regular desenvolvimento até o nascimento com vida. (OLIVEIRA; AMORIM, 2013, p. 32).

Nesse sentido, preconizam Alves e Delgado (2005, p. 918) que o Código Civil:

[...] o se referir a pessoas 'já concebidas', está fazendo alusão ao nascituro, cujo conceito pressupõe gravidez, excluindo, portanto, dentre os legitimados a suceder, o embrião congelado in vitro, bem como os filhos havidos por inseminação artificial ocorrida após a abertura da sucessão.

Ocorre que, de acordo com o artigo 1.597 do Código Civil, presumem-se concebidos na constância do casamento os filhos havidos por fecundação artificial homóloga, mesmo que falecido o marido. Quanto ao caso de inseminação artificial heteróloga, apenas com autorização marital.

Por conta desse dispositivo, há doutrina que entende no sentido contrário, levando-se em conta que se presumem concebidas na constância do casamento as pessoas nascidas, a 
qualquer tempo, quando se tratar de embriões excedentários, decorrentes de concepção artificial homóloga (TARTUCE, SIMÃO, 2013, p. 33). Nesses termos, diz Veloso (2006, p. 1.494):

Não tenho dúvida de garantir que, mesmo depois da morte do pai, vindo o embrião a ser implantado e havendo termo na gravidez, o nascimento com vida e consequente aquisição de personalidade, este filho posterior é herdeiro, porque estava concebido quando o genitor faleceu, e dado ao princípio da igualdade dos filhos da Constituição Federal, art. 227, $\$ 6^{\circ}$.

Cahali e Hironaka (2003, p. 132), muito embora comunguem desse entendimento, tecem críticas:

\begin{abstract}
Embora a contragosto, concluímos terem os filhos assim concebidos o mesmo direito sucessório que qualquer outro filho, havido pelos meios naturais. E estaremos diante de tormentoso problema quando verificado o nascimento após anos do término do inventário, pois toda a destinação patrimonial estará comprometida.
\end{abstract}

Importa, antes de seguir com a análise do assunto, ressaltar que na fecundação artificial homóloga é usado material genético dos próprios pais, cônjuges ou companheiros, o que não se dá na heteróloga, na qual se usa material de terceiros.

O vocábulo fecundação indica a fase de reprodução assistida consistente na fertilização do óvulo pelo espermatozoide. A fecundação ou inseminação homóloga é realizada com sêmen originário do marido. Neste caso o óvulo e o sêmen pertencem à mulher e ao marido, respectivamente, pressupondo-se, in casu, o consentimento de ambos (GONÇALVES, 2014a, p. 307)

Não obstante a importância do estudo do tema também em relação à forma heteróloga de reprodução humana assistida, como já mencionado, a ênfase que se pretende dar no presente artigo é em relação à inseminação homóloga post mortem e suas consequências. Assim, deixamos a análise daquele tema para outra oportunidade.

Feito esse breve parênteses, segue-se salientando que, muito embora o artigo 1.597 do Código Civil reconheça como filiação a fecundação artificial homóloga, Venosa (2011, p. 1.655) preconiza que o dispositivo trouxe mais dúvidas do que pacificações:

\begin{abstract}
Advirta-se, de plano, que este Código não autoriza nem regulamenta a reprodução assistida, mas apenas constata lacunosamente a existência da problemática e procura dar solução ao aspecto da paternidade. Toda essa matéria, cada vez mais ampla e complexa, deve ser regulada por lei específica, por um estatuto ou microssistema. Com esses dispositivos na lei passamos a ter, na realidade, mais dúvidas do que soluções, porque a problemática ficou absolutamente capenga, sem a ordenação devida, não só quanto às possibilidades de o casal optar pela fertilização assistida, como pelas consequências dessa filiação no direito hereditário.
\end{abstract}

Além da ponderação normativa do Código Civil, a reprodução artificial post mortem é tratada na Resolução 1.957/2010 do Conselho Federal de Medicina (2011), que determina que a utilização desse material genético "não constitui ilícito ético a reprodução assistida post 
mortem desde que haja autorização prévia específica do(a) falecido(a) para o uso do material biológico criopreservado, de acordo com a legislação vigente”.

Deve ser analisada, então, a possibilidade desses descendentes concebidos artificialmente terem direito a sucessão de seu pai pré-morto, fazendo-se a ponderação necessária entre o direito fundamental à herança e a segurança jurídica. Andrighi (2011, p. 183) estabelece o parâmetro interpretativo dessa discussão preconizando que:

\begin{abstract}
A hermenêutica jurídica tem, na sua essência, a missão de aclarar aquilo que está obscuro ou "mal dito" na lei, com o fim único de favorecer o ser humano, jamais de prejudicá-lo. Dessa forma, a defesa deste ou daquele posicionamento doutrinário ou jurisprudencial deverá, sim ponderar a respeito das teses nesses contidas, contudo, jamais em detrimento dos seres humanos cujas vidas estão dependendo da intrepidez do espírito que doutrina ou julga.
\end{abstract}

Tecidas essas considerações, na sequência, busca-se, com base na análise do ordenamento jurídico vigente, sopesar a questão da reprodução post mortem e suas consequências sucessórias.

\title{
2. DA SUCESSÃO DOS HERDEIROS CONCEBIDOS POST MORTEM
}

A reprodução artificial citada pelo artigo 1.597 do Código Civil trata-se de uma ficção jurídica, como sendo aquela situação que a lei estabelece como verdade, embora sabendo que aquilo não é verdade, nunca será verdade, mas precisa ser (NOGUEIRA, 20022003 , p. 219). Isto porque, apesar de não haver qualquer possibilidade daquela criança ser concebida de forma natural após o óbito de seu genitor, a lei afirma como nascida na constância do casamento, mesmo sabendo que não o é.

A grande discussão em torno do direito sucessório desses filhos concebidos artificialmente post mortem está na sucessão legítima, eis que a sucessão testamentária tem autorização legislativa expressa no artigo 1.799 e 1.800 do Código Civil, no qual o testador pode contemplar com parte de seu patrimônio os filhos concebidos por sua esposa havidos por fecundação artificial homóloga mesmo após a sua morte.

A inseminação artificial homóloga post mortem é plenamente possível, como referido, no entanto, na linha do aprovado na III Jornada de Direito Civil, deve a mulher estar na condição de viúva e ter o marido deixado por escrito a possibilidade de utilização de seu material para depois de sua morte (GONÇALVES, 2014a, p. 3017), disposição feita por testamento, havendo, não obstante, dúvidas quanto à possibilidade dessa sucessão na forma legal. 


\begin{abstract}
Se o pai, em ato de supremo amor e abnegação, diante do surgimento de súbita enfermidade que lhe impediu de dar continuidade ao sonho da paternidade, manifesta em declaração de última vontade, o desejo de que o material genético que deixou com sua mulher em clínica habilitada para tanto seja utilizado para a reprodução assistida post mortem, poderá essa celebração da vida, mesmo que diante da morte, ter seus efeitos amputados? [...]

Não creio que a dignidade da pessoa humana possa coexistir com outro pensamento, senão com o da prevalência do interesse maior da criança, da solidariedade humana, do direito da criança a uma estrutura familiar equilibrada, e, por fim, da igualdade de tratamento entre pessoas que vivem neste mundo (ANDRIGHI, 2011, p. 183).
\end{abstract}

De acordo com o artigo 1.800 do Código civilista vigente, com o fim do inventário, na sucessão testamentária, os bens dessa "prole eventual" ficarão sobre a responsabilidade de um curador nomeado pelo juiz, e com seu nascimento com vida "ser-lhe-á deferida a sucessão, com os frutos e rendimentos relativos à deixa, a partir da morte do testador" (BRASIL, 2002). Contudo, o $\$ 4^{\circ}$ do mesmo dispositivo, com evidente fulcro na segurança jurídica e na estabilidade das relações, determina que esses herdeiros esperados devem ser concebidos no prazo decadencial de 02 anos da abertura da sucessão, salvo disposição em contrário do testador, sob pena de os bens reservados serem dirigidos aos herdeiros legítimos.

Observa-se que a possibilidade de reconhecimento sucessório a eventual filho, de acordo com autorização testamentária, evita a instabilidade das relações, atribuindo segurança jurídica às transmissões porventura feitas. Nenhum dos sucessores é pego de surpresa com uma gravidez que pode mudar o destino de todos, pois, com a previsão testamentária, tal possibilidade é conhecida desde o momento de abertura da sucessão.

A pergunta crucial, segundo Nogueira (2002-2003, p. 207), e geradora de fortes debates na doutrina, seria: "esse filho concebido após a morte do pai por inseminação artificial homóloga tem direito à sucessão legítima? Porque, quanto à testamentária, é possível, mas quanto à sucessão legítima podemos apresentar duas correntes”. A primeira corrente sustenta que o filho não sucede:

[...] entendem que o filho concebido posteriormente ao óbito do autor da herança
não tem direito à sucessão legítima. Quais seriam os fundamentos? Inicialmente, a
interpretação do art. 1.798, que tem a seguinte redação: "Legitimam-se a suceder as
pessoas nascidas ou já concebidas no momento da abertura da sucessão". Portanto,
para ser herdeiro, ele tem que, ao menos, existir, ter sido concebido até o momento
do óbito. Logo, se o potencial herdeiro ainda não foi concebido, ele ainda não existe,
por isso, não vai ter direito à sucessão legítima Outro fundamento a respaldar esta
posição é aplicabilidade do artigo 1.798, para a sucessão legítima e para a sucessão
testamentária (NOGUEIRA, 2002-2003, p. 207).

A pedra de toque, para essa corrente, seria a segurança jurídica, a estabilidade das relações, pois como seria possível admitir que o concepturo, aquele que ainda não foi concebido (e não se sabe quando será) terá direito a receber esses bens? Quanto tempo esse patrimônio vai ficar reservado para uma concepção que pode nunca ocorrer? Em qual prazo, 
após aberta a sucessão, deverá ocorrer a concepção post mortem? O prazo para pleitear os bens seria o mesmo da petição de herança para este que foi concebido após o óbito, nascendo com vida? Deve ser feita a comunicação das tentativas de concepção futura aos herdeiros existentes? Percebe-se, por conseguinte, a insegurança gerada aos demais herdeiros e interessados na sucessão; mas há, ainda, outro problema sucessório, que seria a intenção da viúva (NOGUEIRA, 2002-2003, p. 208).

Esta primeira corrente também argumenta suscitando o direito adquirido dos herdeiros concebidos e já nascidos à sucessão legítima, por terem direito de saisine, porquanto o artigo 1.784 do Código Civil prevê que aberta a sucessão, a herança transmite-se, desde logo, aos herdeiros legítimos e testamentários. Com o falecimento, imediatamente o domínio e a posse são transmitidos aos herdeiros existentes e a Constituição da República assegura o direito adquirido e o direito à herança, ambos em seu artigo $5^{\circ}$, protegido como cláusula pétrea. Portanto, para essa parte da doutrina, admitir que o concebido após o óbito suceda, contraria estes preceitos fundamentais.

O problema, neste caso, está relacionado à ausência de comunicação e ciência, já que os demais sucessores sequer precisam saber dessas tentativas de procriação artificial, podendo ser pegos de surpresa a qualquer momento. Nesse sentido, quem não estiver concebido até a data da morte do autor da herança não está legitimado a suceder. Na sucessão testamentária, porém, como estudado, pode haver o chamamento do nondum conceptus (pessoa futura, pessoa ainda não concebida). Para Venosa (2011, p. 1.895), “o ordenamento não prevê qualquer modalidade de sucessão para os nascidos ou concebidos após a morte do autor da herança se não houve previsão no ato de última vontade".

Já a parte da doutrina que é a favor da sucessão legítima desse filho usa como fundamento a igualdade entre os filhos estabelecidas no artigo $227, \S 6^{\circ}$, da Constituição Federal de 1988. Consignam esses autores que não há fundamento para que filhos concebidos antes sejam sucessores e filhos concebidos post mortem não sejam.

O segundo argumento utilizado por essa corrente é a dignidade da pessoa humana, porquanto "não se pode sustentar um comportamento familiar, uma convivência digna numa família de um filho com patrimônio deixado pelo falecido pai e um outro filho, sem patrimônio, dependente, completamente, dos seus familiares" (NOGUEIRA, 2002-2003, p. 209).

A problemática se agrava com o Enunciado 267 da III Jornada de Direito Civil (CONSELHO DA JUSTIÇA FEDERAL, 2005, p. 399-401), na qual foi aprovada a seguinte redação: 
A regra do art. 1.798 do Código Civil deve ser estendida aos embriões formados mediante o uso de técnicas de reprodução assistida, abrangendo, assim, a vocação hereditária da pessoa humana a nascer cujos efeitos patrimoniais se submetem às regras previstas para a petição da herança.

Tal Enunciado é fruto da proposição trazida pelo Juiz Federal Dr. Guilherme Calmon Nogueira da Gama, que tratou do congelamento de embriões e da criopreservação de sêmen ou óvulo para futura utilização, e consequente reconhecimento de direitos sucessórios (CONSELHO DA JUSTIÇA FEDERAL, 2005, p. 399-401).

De acordo com a justificativa do Enunciado, partindo-se da premissa que a redação do Código Civil se iniciou ainda na década de 60, o legislador não tinha condições de imaginar tal evolução científica, resumindo sua atividade a adotar a regra do art. 1718 do Código Civil de 1916 ("são absolutamente incapazes de adquirir por testamento os indivíduos não concebidos até a morte do testador, salvo se a disposição deste se referir á prole eventual de pessoas por ele designadas e existentes ao abrir-se a sucessão") (BRASIL, 1916). Nesse sentido, Gama defende a interpretação extensiva do art. 1.798, do atual Código Civil, dispondo que:

[...] a melhor solução é considerar que o art. 1.798 do novo Código Civil disse menos do que queria, devendo o intérprete proceder ao trabalho de estender o preceito aos casos de embriões já formados e àqueles a se formar (abrangendo, assim, as duas hipóteses indicadas) (CONSELHO DA JUSTIÇA FEDERAL, 2005, p. 401).

De acordo com a proposição apresentada, no caso da criança nascer depois de findo o inventário e partilha, a situação seria facilmente resolvida pela ação de petição de herança, do artigo 1.824 e seguintes do Código Civil, se dentro de seu prazo prescricional de 10 anos (artigo 205 do Código Civil) (CONSELHO DA JUSTIÇA FEDERAL, 2005, p. 401).

Dentro dessa análise, importante ressaltar a ponderação feita por Alarcón (2004, p. 58) ao tratar da proteção da vida humana:

\footnotetext{
Obviamente que não pode ser a lei, nem nenhum ordenamento jurídico-positivo, que vai conferir ao homem a vida e todas as demais faculdades naturais; entretanto, ao Direito lhe compete sim dar proteção e assegurar o pleno desenvolvimento destas faculdades, em condições de equilíbrio do indivíduo em relação o grupo e deste em relação ao indivíduo.
}

Permitir a concepção artificial post mortem é muito mais do que considerar tal concepção realizada na constância do casamento, é muito mais do que considerar essa criança filha de alguém que morreu antes mesmo de sua implantação no ventre materno. Tratar dessa concepção é tratar dos direitos sucessórios dessa criança e de sua mãe, que podem ser modificados, a depender da existência ou inexistência de descendentes comuns, ou até mesmo da inexistência prévia de descendentes, e com essa modificação podem atingir direitos de 
outros descendentes e até mesmo de ascendentes, se analisarmos a hipótese do artigo 1.836 do Código Civil, que determina: "na falta de descendentes, são chamados à sucessão os ascendentes, em concorrência com o cônjuge sobrevivente" (BRASIL, 2002).

Embora vários posicionamentos tenham sido trazidos, todos válidos na medida em que possuem fulcro constitucional, certo é que, enquanto não houver atividade legislativa regulamentadora ou a fixação de um posicionamento nos Tribunais Superiores, não haverá pacificação sobre o assunto, restando todo o trabalho à ponderação dos princípios constitucionais.

$\mathrm{Na}$ verdade, quanto à sucessão testamentária, não haveria óbice, principalmente porque no momento de sua abertura os demais herdeiros e legatários já tomariam ciência da possibilidade de existência de prole futura. Porém, quanto à sucessão legítima, a situação não se mostra tão confortável, sendo evidente que existe um conflito entre princípios constitucionais, direitos fundamentais e direitos sucessórios.

\section{A CONCEPÇÃO POST MORTEM E O PRINCÍPIO DA SEGURANÇA JURÍDICA}

Indubitavelmente, a prole concebida post mortem, com amparo na Constituição e no

Código Civil, terá o direito de herança e o direito de propriedade e, sendo filho, deve ser considerado como herdeiro, tendo direito de saisine.

Mas, não havendo qualquer autorização testamentária, ou se, embora havendo, a concepção ocorrer já decorridos dois anos após a abertura da sucessão, sem que o testador tenha deixado qualquer disposição em contrário, diversas questões surgem e causam tormento.

Isto porque os outros filhos pré-concebidos, os outros herdeiros, também têm direito de saisine, porquanto o domínio e a posse foram imediatamente transmitidos na hora do óbito. Se for imediatamente transmitido no exato momento do falecimento, eles têm direito adquirido a um determinado percentual daquela herança, têm o direito de propriedade e o direito de herança garantidos pela Constituição aos bens que compõem o acervo hereditário.

O problema que se coloca, por conseguinte, nos casos acima descritos, é justamente decorrente da insegurança jurídica que tal situação inevitavelmente traz aos herdeiros préconcebidos. "Na verdade, existe um conflito de normas fundamentais que deve ser dirimido pela teoria da ponderação dos interesses. As duas linhas argumentativas trazem à cena a inevitabilidade de colisão de direitos e princípios fundamentais" (NOGUEIRA, 2002-2003, p. 209). 
Assim, pode-se visualizar, de um lado, o direito do filho concebido post mortem à sucessão, com base na dignidade da pessoa humana, no direito à propriedade, à herança, na igualdade de tratamento a ser dispensado aos filhos. Além disso, o princípio da paternidade responsável, que pode ultrapassar o período de vida do genitor, gera o dever de propiciar aos filhos meios materiais de sobrevivência e vida digna.

Em contraposição, estaria o direito dos demais herdeiros existentes à época do óbito, com baseamento na segurança das relações jurídicas, na previsão do artigo 1.798 do Código Civil, e também no direito de propriedade, no direito de herança, no direito adquirido e, porque não, também com fulcro na dignidade da pessoa humana, já que essa incerteza pode afetar os mais diversos direitos fundamentais desses herdeiros, até mesmo o direito à vida, na medida em que necessitem desses bens para garantir sua sobrevivência.

Como se defere das linhas acima, admitir direitos sucessórios a filiação decorrente de concepção artificial homóloga post mortem, não autorizada em testamento, gera muito mais problemas do que acertos. Trata-se, verdadeiramente, de uma hipótese de insegurança jurídica trazida pelo sistema, sendo que a interpretação dos dispositivos legais não deve se dar de forma tão extensiva, a ponto de prejudicar a segurança jurídica e o direito adquirido.

Um casal, ao iniciar as tratativas e os procedimentos para a inseminação artificial, não tem qualquer obrigação legal de comunicar a sua família, ou a qualquer órgão, sobre tal atitude, o que coaduna com a liberdade à vida íntima e privada, e inclusive com o $\$ 7^{\circ}$ do artigo 226, da Constituição Federal de 1988, que trata da liberdade do planejamento familiar.

\footnotetext{
O direito ao planejamento familiar, assim, é um direito a ser livremente exercido, mas apenas no sentido de não admitir qualquer ingerência de outrem, estatal ou privada, com vistas a restringi-lo ou condicioná-lo, uma vez que a decisão sobre ter ou não prole, seu aumento ou redução vincula-se à privacidade e à intimidade do projeto de vida individual e parental dos envolvidos (MORAES; TEIXEIRA, 2013, p. 5.010).
}

No entanto, não comunicar a decisão de concepção de prole post mortem gera insegurança e disso não há dúvida. Um exemplo simples, usando como base o entendimento trazido pelo Enunciado 267, pode ser dado: um homem, separado e com filhos desse primeiro casamento, contrai segundas núpcias. O casal, na constância do casamento, decide começar a fazer uso das técnicas de inseminação artificial com o uso de seu próprio material genético. Dirigem-se até uma clínica e dão início aos procedimentos. No transcorrer das tentativas o marido vem a óbito, a esposa cai em uma profunda fase de luto e para de fazer as tentativas, no entanto, o material do marido continua armazenado em laboratório. Nesse caso é feito inventário e partilha de todos os bens, com a convocação dos herdeiros necessários do falecido. 
Com o fim da partilha, os bens são transmitidos a seus novos proprietários, que passam a dar a destinação que lhes convêm a seu novo patrimônio, respeitando a função social da respectiva propriedade.

Aproximadamente seis anos após a morte do marido, a esposa, em um momento de profunda saudade, volta a realizar a reprodução artificial, ficando grávida do marido prémorto, nascendo tal criança com vida nove meses depois. Porém, nenhum dos demais herdeiros conhecia tal possibilidade, sequer sabendo das tentativas anteriores de reprodução.

De acordo com o entendimento do Enunciado 267, já analisado, é possível que essa mãe, representando seu filho, ajuíze uma ação de petição de herança, para obter uma nova partilha, nos moldes permitidos pelos artigos 1.824 e seguintes do Código Civil.

É possível, assim, que esses herdeiros anteriores sejam prejudicados por ato alheio a sua vontade, do qual sequer tinham conhecimento da possibilidade? E na hipótese de a sucessão ter se dado entre o cônjuge e os ascendentes, nos moldes do art. 1.836 do Código Civil, como ficaria agora com a existência de descendente, os ascendentes perderiam todo o herdado?

Nota-se, de plano, que permitir a interpretação favorável à atribuição de direito sucessório a tal filho, inclusive com a aplicação das regras atinentes à petição de herança, afronta a segurança jurídica, a estabilidade das relações jurídicas findas. Segundo Rothenburg (2014, p. 184), “não se trata apenas de assegurar juridicamente o que já foi obtido ou poderia sê-lo, com vistas ao passado. Trata-se ainda de assegurar juridicamente, no presente, aquilo que o direito oferece, de modo adequado e racional".

A segurança jurídica é um dos princípios basilares do Estado Democrático de Direito (SILVA, 2005, p. 122), e encontra amparo no ordenamento jurídico pátrio. Juntamente com os demais princípios gerais do Direito, a segurança jurídica confere proteção e confiança à ordem jurídica e social. Analisando esse princípio, Mello (2008, p. 124-125) afirma, pontualmente, que "o Direito propõe-se a ensejar certa estabilidade, um mínimo de certeza na regência da vida social”, sendo que "esta segurança jurídica coincide com uma das mais profundas aspirações do homem: a da segurança em si mesma".

Canotilho (1991, p. 384) diz que o princípio da segurança jurídica, que ele prefere tratar como princípio da estabilidade das relações jurídicas, é uma das vigas mestras da ordem jurídica, de suma importância na atualidade.

\footnotetext{
A segurança jurídica, desse modo, consiste no conjunto de condições que tornam possível às pessoas o conhecimento prévio das consequências diretas de seus atos e de seus fatos à luz da liberdade reconhecida. Uma importante condição da segurança jurídica está na relativa certeza de que os indivíduos têm de que as relações
} 
realizadas sob o império de uma norma devem perdurar ainda quando tal norma seja substituída (SILVA, 2005, p. 433).

O princípio da segurança jurídica pode ser vislumbrado no ordenamento jurídico brasileiro no artigo $5^{\circ}$, inciso XXXVI, da Constituição da República (BRASIL, 1988), que determina: "a lei não prejudicará o direito adquirido, o ato jurídico perfeito e a coisa julgada". Como ensina Mendes (2013, p. 873), a ideia central do dispositivo está ligada à de segurança jurídica, uma das expressões máximas do Estado de Direito. Logo, a segurança jurídica é um princípio constitucional implícito, disciplinado dentre os direitos e garantias fundamentais.

Quanto ao conceito da expressão, Ramos (2014, p. 589) diz que "o direito à segurança jurídica consiste na faculdade de obstar a extinção ou a alteração de determinado ato ou fato jurídico, posto a salvo de modificações futuras, inclusive legislativas".

A segurança jurídica, portanto, encontra-se intimamente vinculada aos conceitos de direito adquirido, ato jurídico perfeito e coisa julgada. Tais conceitos são trazidos pelo artigo $6^{\circ}$ da Lei de Introdução às Normas do Direito Brasileiro (atual denominação da LICC) (BRASIL, 1942), que dispõe, em seu $§ 2^{\circ}$ que: "consideram-se adquiridos assim os direitos que o seu titular, ou alguém por ele, possa exercer, como aqueles cujo começo de exercício tenha termo pré-fixo, ou condição preestabelecida inalterável a arbítrio de outrem". O ato jurídico perfeito seria, por sua vez, o "já consumado segundo a lei vigente ao tempo em que se efetuou" $\left(\S 1^{\circ}\right)$. E a coisa julgada ou caso julgado, "a decisão judicial de que já não caiba mais recurso" $\left(\S 3^{\circ}\right)$. "De qualquer sorte, é certo que, a despeito dessa formal tripartição, o conceito central é o conceito de direito adquirido, nele estando contemplados, de alguma forma, tanto a ideia de ato jurídico perfeito como a de coisa julgada" (MENDES, 2013, p. 874).

A segurança jurídica também está acoplada ao princípio da legalidade, disciplinado no artigo $5^{\circ}$, inciso II, da Constituição Federal (BRASIL, 1988), segundo o qual "ninguém será obrigado a fazer ou deixar de fazer alguma coisa senão em virtude de lei”. O princípio da legalidade traduz a concepção moderna de lei como instrumento de proteção das liberdades individuais:

\footnotetext{
A Constituição de 1988 , em seu art. $5^{\circ}$, II, traz incólume, assim, o princípio liberal de que somente em virtude de lei podem-se exigir obrigações dos cidadãos. Ao incorporar essa noção de lei, a Constituição brasileira torna explícita a intrínseca relação entre legalidade e liberdade. A lei é o instrumento que garante a liberdade (MENDES; VALE, 2013, p. 545).
}

Não há como negar, portanto, que o Estado Democrático de Direito esteja construído sobre o conceito de lei, porquanto é da essência de seu conceito subordinar-se à Constituição e fundar-se na legalidade democrática (SILVA, 2005, p. 420). "O princípio da legalidade 
permanece insubstituível como garantia dos direitos e como fundamento e limite a todo funcionamento do Estado" (MENDES, VALE, 2013, p. 546).

A lei, aqui, deve entendida como expressão da vontade geral, ato legislativo emanado dos órgãos de representação popular e confeccionada segundo o processo legislativo estabelecido na Constituição. Porém, o princípio da legalidade vincula-se a uma reserva genérica ao Poder Legislativo, que não exclui atuação secundária de outros poderes (SILVA, 2005, p. 421).

Correlatos à ideia de segurança jurídica também são os conceitos de prescrição e decadência. Isto porque, desde a concepção do ser humano, o tempo influi nas relações jurídicas de que o indivíduo participa. No campo jurídico, portanto, a interferência do elemento tempo é substancial, pois existe interesse da sociedade em atribuir juridicidade àquelas situações que se prolongaram no tempo (GONÇALVES, 2013, p. 478).

Tais institutos são necessários, por conseguinte, para que haja tranquilidade na ordem jurídica, para a consolidação de todos os direitos. Sem eles, nada seria permanente, o proprietário jamais estaria seguro de seus direitos, e o devedor livre de pagar duas vezes a mesma dívida. Sobre a distinção entre os conceitos, ensina Gonçalves (2013, p. 478):

\footnotetext{
Para distinguir prescrição de decadência, o atual Código Civil optou por uma fórmula que espanca qualquer dúvida. Prazos de prescrição são, apenas e exclusivamente, os taxativamente discriminados na Parte Geral, nos arts. 205 (regra geral) e 206 (regras especiais), sendo de decadência todos os demais, estabelecidos como complemento de cada artigo que rege a matéria, tanto na Parte Geral como na Especial. Para evitar a discussão sobre se ação prescreve, ou não, adotou-se a tese da prescrição da pretensão, por ser considerada a mais condizente com o Direito Processual contemporâneo.
}

Segundo Lisboa (2012, p. 462), prescrição é a perda do direito de pretensão judicial pelo decurso do prazo previsto em lei. Configura, de certa forma, uma renúncia tácita do direito subjetivo de pretensão (ação processual, instrumental ou adjetiva), pelo decurso do tempo, que impossibilita a prestação jurisdicional.

A prescrição extingue o direito porque o seu titular deixa de ter qualquer ação para assegurá-lo, em virtude da sua inércia no período de tempo previsto em lei. "Há prescrição sempre que uma pessoa tiver a obrigação de exercer qualquer prestação em favor de outra, porém o beneficiário não vem exigi-la judicialmente no prazo legal” (LISBOA, 2012, p. 462).

Já a decadência é a perda do direito potestativo pela inércia do seu titular no período determinado em lei. Seu objeto são os direitos potestativos de qualquer espécie, disponíveis ou indisponíveis, direitos que conferem ao respectivo titular o poder de influir ou determinar mudanças na esfera jurídica de outrem, por ato unilateral, sem que haja dever correspondente, apenas uma sujeição. 


\begin{abstract}
Um dos critérios usados pela doutrina para distinguir prescrição de decadência consiste em considerar que, nesta, o prazo começa a fluir no momento em que o direito nasce. Desse modo, no mesmo instante em que o agente adquire o direito já começa a correr o prazo decadencial. O prazo prescricional, todavia, só se inicia a partir do momento em que este tem o seu direito violado. Também se diz que a prescrição resulta exclusivamente da lei, enquanto a decadência pode resultar da lei (legal), do testamento e do contrato (convencional) (GONÇALVES, 2013, p. 299).
\end{abstract}

A decadência, assim, é instituto do direito substantivo: há a perda de um direito previsto em lei. O legislador estabelece que certo ato terá que ser exercido dentro de um determinado tempo, fora do qual ele não poderá mais efetivar-se porque dele decaiu o seu titular. "A decadência se consubstancia, pois, no decurso infrutífero de um termo prefixado para o exercício do direito. O tempo age em relação à decadência como um requisito do ato, pelo que a própria decadência é a sanção consequente da inobservância de um termo" (GONÇALVES, 2013, p. 500).

Retornando especificamente ao tema proposto, como já analisado acima, na sucessão testamentária, nos termos do artigo 1.799, I, do Código Civil, há a possibilidade de atribuir bens à prole eventual, ou seja, "os filhos, ainda não concebidos, de pessoas indicadas pelo testador, desde que vivas estas ao abrir-se a sucessão" (BRASIL, 2002). Aí se incluem mesmo os concebidos depois da morte do autor da herança, como descendentes das pessoas designadas pelo testador (OLIVEIRA; AMORIM, 2013, p. 33).

A prole eventual, por abranger descendência futura, demanda a nomeação de um curador para administrar os bens da herança que se lhe atribua. Dispõe nesse sentido o artigo 1.800 do Código Civil, acrescentando, no $\S 3^{\circ}$, que, nascendo com vida o herdeiro esperado, ser-lhe-á deferida a sucessão, com os frutos e rendimentos relativos. Mas, essa atribuição é condicionada ao nascimento de filho no prazo de dois anos da abertura da sucessão. Decorrido esse tempo, sem que seja concebido o herdeiro esperado, os bens reservados, salvo disposição

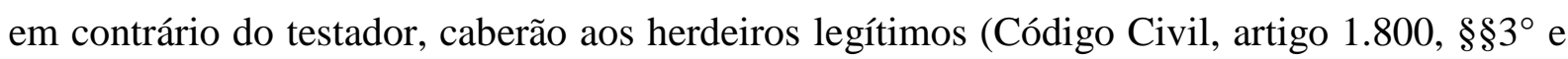
$4^{\circ}$ ) (OLIVEIRA; AMORIM, 2013, p. 34).

Além do fato de a possibilidade de descendência futura estar prevista em testamento, o que já confere previsibilidade aos demais herdeiros, é justamente a previsão do prazo decadencial de 2 anos da abertura de sucessão, ou previsão expressa no testamento em sentido contrário, que confere segurança jurídica a essa concepção post mortem.

Quanto à sucessão legítima, conforme estudado anteriormente, há uma lacuna normativa. Não há na lei qualquer prazo decadencial para a concepção e, principalmente, não há nada que obrigue a comunicação prévia aos demais herdeiros sobre a possiblidade de descendência futura após o óbito do de cujus. 
Não há dúvida, por conseguinte, de que o direito de herança desse filho gerado post mortem deve ser ponderado com a segurança jurídica e a estabilidade das relações. Não há razoabilidade de voltar a um status quo ante, de uma partilha que foi feita nos moldes da lei, amparada na boa-fé de seus participantes, que em momento algum tiveram qualquer conhecimento da possibilidade dessa concepção post mortem.

Trata-se de atitude desproporcional. O direito de herança modificado posteriormente, por ato e decisão exclusiva da viúva, sem qualquer comunicação prévia aos demais herdeiros no momento do inventário e da partilha, afronta veementemente a segurança jurídica, a confiança que deve pautar as relações jurídicas, inclusive, podendo gerar embaraços e desenlaces familiares. Trata-se de tumulto gerado por ato unilateral e exclusivo da viúva. Dúvida há, obviamente, quanto à boa-fé da viúva que assim age, principalmente se sua situação sucessória também mudar.

Tal conjuntura, portanto, não merece amparo pelo Direito, por violar instituições tão importantes quanto o direito de herança, o direito de propriedade, a segurança jurídica e o direito adquirido. Não há dúvidas que à prole concebida post mortem devem ser assegurados os direitos de herança, de alimentação, de sobrevivência digna. Porém, não se pode deixar de considerar também a dignidade dos herdeiros já existentes.

\section{CONCLUSÃO}

Que o direito de herança é amplamente amparado em nosso sistema jurídico não há dúvida, inclusive sendo um direito fundamental protegido pelo artigo $5^{\circ}$ da Constituição Federal; porém, como todo e qualquer direito fundamental, não é absoluto, principalmente quando confrontado com outro direito fundamental.

Defender juridicamente a sucessão de filhos concebidos por inseminação homóloga post mortem, quando tal possiblidade está autorizada em testamento, não causa qualquer instabilidade na relação dos sucessores já concebidos ou nascidos na data do óbito. Ao contrário, a sucessão testamentária é aberta trazendo ao conhecimento de todos os envolvidos tal possibilidade. A prole eventual, de uma forma ou outra, já passa a fazer parte da sucessão, seja como algo incerto, porém, previsível.

Mas, conferir direitos sucessórios à prole futura concebida post mortem, não havendo qualquer autorização testamentária, ou, embora havendo, a concepção ocorrer decorridos dois anos após a abertura da sucessão, sem que o testador tenha deixado qualquer disposição em contrário, gera insegurança e instabilidade nas sucessões. Não trazendo a lei exigências para 
tal concepção e ficando as normas infraconstitucionais abertas a interpretações diversas, não há como prever suas consequências.

Desse modo, não haveria qualquer razoabilidade caso se permitisse a sucessão legítima post mortem, com base na prescrição da ação de herança, em situações como as descritas. Não se propugna, contudo, que o direito sucessório da prole concebida post mortem, sem autorização testamentária, não possa ser reconhecido. Porém, o que se pretende asseverar é que, da maneira como hoje está disciplinada a questão, conferir direito de herança nessas situações violaria direitos fundamentais dos demais herdeiros e geraria insegurança jurídica à sociedade, o que não deve ser abonado pelo Direito.

Para que referido direito fosse reconhecido, salutar seria a atuação do legislador infraconstitucional, fixando requisitos mínimos para essa concepção post mortem gerar efeitos quanto à sucessão legítima e estabelecendo quais seriam as consequências jurídicas. $\mathrm{Na}$ ausência da lei, poder-se-ia cogitar da possibilidade de o Judiciário fixar esses paradigmas.

Neste caso, entretanto, não bastaria ao Judiciário dizer sobre a possibilidade ou não de tal sucessão, mas sim fixar os parâmetros para a permissão de tal concepção, o seu prazo, o prazo para a petição de herança, se haveria necessidade de comunicação prévia aos herdeiros legítimos, se seriam reservados bens, como os herdeiros seriam ressarcidos pelas benfeitorias realizadas, como seria realizada a restituição ao monte mor em caso de venda do bem, além de outras dúvidas que podem surgir sobre o patrimônio do de cujus, já que é certo que os herdeiros existentes não podem ficar eternamente à mercê da vontade unilateral da viúva.

Observa-se, portanto, que auferir direito sucessório legítimo ao herdeiro concebido post mortem não é uma questão tão simples como alguns anseiam. Muitas normas de conduta devem fixadas para não prejudicar o direito de herdeiros e de terceiros, sendo simplória a interpretação desse direito com base apenas na proteção constitucional do direito de herança e no princípio da igualdade entre os filhos.

Desse modo, nos termos da legislação existente, não sendo permitido ao Judiciário se esquivar de prestar a tutela jurisdicional, conclui-se pela possibilidade da sucessão post mortem quando testamentária, porém pela impossibilidade na sucessão legítima, pois tal situação não merece amparo pelo Direito, por violar instituições tão importantes quanto o direito à herança, o direito de propriedade, o direito adquirido e a segurança jurídica.

Não há dúvidas que à prole concebida post mortem devem ser assegurados os direitos de filiação, de sucessão, de alimentação, de sobrevivência digna. Porém, não se pode deixar de considerar também a dignidade e os direitos fundamentais dos herdeiros já existentes. Logo, havendo interesse em ver reconhecidos direitos sucessórios de prole futura concebida 
post mortem, deverá o indivíduo se acautelar de resguardar essa pretensão inadvertidamente em declaração de última vontade.

\section{REFERÊNCIAS BIBLIOGRÁFICAS}

ALARCÓN, Pietro de Jesús Lora. Patrimônio Genético Humano e sua Proteção na Constituição Federal de 1988. São Paulo: Método, 2004.

ALVES, Jones Figueiredo; DELGADO, Mário Luiz. Código Civil Anotado. São Paulo: Método, 2005.

ANDRIGHI, Fátima Nancy. A Sucessão do filho gerado post mortem por meio de reprodução homóloga assistida. In: GUERRA, Luiz (Coord.). Temas Contemporâneos do Direito: homenagem ao bicentenário do Supremo Tribunal Federal. Brasília: Guerra, 2011, p. 183185.

BRASIL. Lei 3.071, de $1^{\circ}$ de janeiro de 1916. Código Civil dos Estados Unidos do Brasil. Diário Oficial da União, Rio de Janeiro, DF, 5 jan. 2016. Disponível em: <http://www.planalto.gov.br/ccivil_03/leis/L3071impressao.htm>. Acesso em: 20 jul. 2015.

. Decreto-Lei n. 4.657, de 4 de setembro de 1942. Lei de Introdução às Normas do Direito Brasileiro. Redação dada pela Lei n. 12.376, de 2010. Diário Oficial da União, Rio de Janeiro, DF, 09 set. 1942, republicada em 31 dez. 2010. Disponível em: <http://www.planalto.gov.br/ccivil_03/decreto-lei/Del4657compilado.htm>. Acesso em: 16 ago. 2015.

. Constituição da República Federativa do Brasil, de 05 de outubro de 1988. Diário Oficial da União, Brasília, DF, 05 out. 1988. Disponível em: <http://www.planalto.gov.br/ccivil_03/constituicao/constituicao.htm>. Acesso em: 02 jul. 2015.

Lei 10.406, de 10 de janeiro de 2002. Institui o Código Civil. Diário Oficial da União, Brasília, DF, 11 jan. 2002. Disponível em: <http://www.planalto.gov.br/ccivil_03/Leis/2002/L10406.htm>. Acesso em: 19 jul. 2015.

CAHALI, Francisco José; HIRONAKA, Giselda Maria Fernandes Novaes. Curso Avançado de Direito Civil. Direito das Sucessões. 2. ed. rev. e atual. São Paulo: Revista dos Tribunais, 
2003, v. 6 .

CANOTILHO, José Joaquim Gomes. Direito Constitucional. 4 ed. Coimbra: Almedina, 1991.

CONSELHO DA JUSTIÇA FEDERAL. III Jornada de Direito Civil. Brasília: CJF, 2005.

Disponível em:

<http://daleth.cjf.jus.br/revista/outras_publicacoes/jornada_direito_civil/IIIJornada.pdf>.

Acesso em: 20 jul. 2015.

CONSELHO FEDERAL DE MEDICINA. Resolução 1.957 de 06 de janeiro de 2011.

Disponível em: <http://www.portalmedico.org.br/resolucoes/CFM/2010/1957_2010.htm>. Acesso em: 20 jul. 2015.

GONÇALVES, Carlos Roberto. Direito Civil Brasileiro: Parte Geral. 11 ed. São Paulo: Saraiva, 2013, v. 1, e-book.

. Direito Civil Brasileiro: Direito de Família. 11 ed. São Paulo: Saraiva, 2014, v. 6.

Direito Civil Brasileiro: Direito das Sucessões. 8 ed. São Paulo: Saraiva, 2014, v. 7, e-book.

LISBOA, Roberto Senise. Manual de Direito Civil: Teoria Geral do Direito. 7 ed. São Paulo: Saraiva, 2012, v. 1, e-book.

MELlO, Celso Antônio Bandeira De. Curso de Direito Administrativo. 18. ed. São Paulo: Malheiros, 2008.

MENDES, Gilmar Ferreira. Artigo 5, XXXVI. In: CANOTILHO, J.J. Gomes; MENDES, Gilmar Ferreira; SARLET, Ingo Wolfgang; STRECK, Lenio Luiz (Coord.). Comentários à Constituição do Brasil. São Paulo: Saraiva/Almedina, 2013, e-book.

- VALE, Andre Rufino. Artigo 5, II. In: CANOTILHO, J.J. Gomes; MENDES, Gilmar Ferreira; SARLET, Ingo Wolfgang; STRECK, Lenio Luiz (Coord.). Comentários à Constituição do Brasil. São Paulo: Saraiva/Almedina, 2013, e-book. 
METRING, Roberto Araújo. Pesquisas Científicas: Planejamento para Iniciantes. Curitiba: Jurúa, 2011.

MORAES, Maria Celia Bodin de; TEIXEIRA, Ana Maria Brochado. Comentário ao artigo 226. In: CANOTILHO, J.J. Gomes.et al. (Coord.) Comentários à Constituição do Brasil. São Paulo: Saraiva/Almedina, 2013, p. 4994-5023, e-book.

NOGUEIRA, Claudia. O direito sucessório do não concebido ao tempo do óbito e algumas inovações na sucessão testamentária. Anais do "EMERJ Debate o Novo Código Civil". Revista da Escola da Magistratura do Rio de Janeiro (EMERJ), Anais dos Seminários EMERJ Debate o Novo Código Civil, parte II, julho/2002 a abril/2003, p. 207-220. Disponível em: <http://www.emerj.rj.gov.br/revistaemerj_online/edicoes/anais_onovocodigocivil/anais_espec ial_2/Anais_Parte_II_revistaemerj.pdf>. Acesso em: 02 ago. 2015.

OLIVEIRA, Euclides da; AMORIM, Sebastião Luiz. Inventários e Partilhas. Direito das Sucessões - teoria e prática. 23. ed. ver. atual. São Paulo: Universitária de Direito, 2013.

PEREIRA, Caio Mario da Silva. Instituições de Direito Civil: Direito das Sucessões. 13 ed. Rio de Janeiro: Forense, 2001, v. 6.

POLETTO, Carlos Eduardo Minozzo. Indignidade Sucessória e Deserdação. São Paulo: Saraiva, 2013.

RAMOS, André de Carvalho. Curso de Direitos Humanos. São Paulo: Saraiva, 2014.

ROTHENBURG, Walter Claudius. Direitos Fundamentais. São Paulo: Método, 2014.

SILVA, José Afonso. Curso de Direito Constitucional Positivo. 25 ed. rev. atual. São Paulo: Malheiros, 2005.

SILVA, Regina Beatriz Tavares da (Coord.). Código Civil Comentado. 8 ed. São Paulo: Saraiva, 2012.

TARTUCE, Flávio; SIMÃO, José Fernando. Direito Civil: Direito das Sucessões. 6 ed. São 
Paulo: Método, 2013, v. 6, e-book.

VELOSO, Zeno. Novo Código Civil Comentado. São Paulo: Saraiva, 2006.

VENOSA, Sílvio de Salvo. Código Civil Interpretado. 2. ed. São Paulo: Atlas, 2011. 